JOSAR, Vol. 1 No. 1 March 2019; p-ISSN: 2502-8251; e-ISSN: 2503-1155

Copyrights@Balitar Islamic University, Blitar-Indonesia https://ejournal.unisbablitar.ac.id/index.php/josar

\title{
ENGLISH KEREN REK (EKR) WEB BASE GAME APPLICATION MODEL TO ENRICH X GRADE STUDENTS' ENGLISH GRAMMAR ACHIEVEMENT
}

\author{
Hestiningrum, Yunita Sari Putri ${ }^{1}$; Supriyono ${ }^{2}$; Aini, Miza Rahmatika ${ }^{3}$. \\ ${ }^{1,2,3,}$ English Department, Balitar Islamic University \\ E-mail: 1'ys255588@gmail.com, 2yonsupriyono@gmail.com \\ jumintenlarasati@gmail.com
}

\begin{abstract}
This research was aimed at establishing, describing the implementation, and finding out the influence of the English Keren Rek (EKR) Web Base Game Application Model. This research applied Qualitative and Quantitative approches with Research and Development Design by using adapted Sugiyono's Model. This research consisted of three phases, which were first: foundational research to identify potencies and problems; second: design and development research; and third: experimental research. The valid final model contained of opening, home display, games display, learning materials, and evaluation. The validation score of overall model components was $77.75 \%$ which meant very propper. The tests validity and reliability values were (0.999) by alpa Corn-batch and (0.999) by using split half technique. The one-group pre and post test experimental research showed that before using the model, the average students' achievement was (51) and after using the model it reached (85.05) by which the students gained (34.05) which meant 60\% increase of the mean score. Having the value of t-test with $t_{\text {count }}-35.556<t_{\text {tabel }} 2.03011$ by Significant value of 0.05, this showed that the model positively influenced the students' grammar achievement. The implementation turned out to be interesting and motivating.
\end{abstract}

Key Words: English Keren Rek, Web Base Game, Application Model, English Grammar Achievement.

\section{Introduction}

The policy study on the national education decreed of number 2013 reveals that the motion of the national education goals and instruction of English as a foreign language. According to a Law No. 20 Year 2003 (Undang-Undang No.20 Tahun 2003), "Education is an effort that is done continuously and planned to realize learning situation and learning process so that the learner actively develop his potential to have spiritual strength, self-control, personality, intelligence, noble character, and skills needed by himself, society, nation, and country". This means that education is a manner to teach, learn and practice knowledge and skill which is needed by each person to self-development as a provision to prepare future. The knowledge and skill that have learned can be implemented in their life and society exactly. 
JOSAR, Vol. 1 No. 1 March 2019; p-ISSN: 2502-8251; e-ISSN: 2503-1155

Copyrights@Balitar Islamic University, Blitar-Indonesia https://ejournal.unisbablitar.ac.id/index.php/josar

The goals of education in Indonesia have been stated in a Law No. 20 Year 2003 (Undang-Undang. No.20 Tahun 2003) about National Education System in article 3, which developing students' potential to be religious and pious to God, noble moral, healthy, knowledgeable, competence, creative, independent, and to be democratic and responsible citizen. The goals were implemented through national education which is in organized using national curriculum.

Curriculum is a set of learning system. Indonesia has established and implemented 2013 curriculum for all element educational institution. The goals of 2013 curriculum based on Law of Educational and Cultural Minister (Permendikbud) No. 69 year 2013 about basic framework and curriculum structure: preparing Indonesian people to have the ability to live as individuals and citizens who are faithful, productive, creative, innovative, and affective and citizens contribute to the life of the world, nation, state, and world civilization. For shorter goal, 2013 curriculum is used to improve students' skill like cognitive, affective, psychomotor, and social. A part of these goals was also an effort to create human culture through languages. Language could not be separated with human life. It is used to communicate between individual to individual, individual to group, and group to group. Every language is arranged by the roles of language whose function to express ideas and contained meaning.

English as a foreign language became the interest of the researcher in high school. On the basis of the 2013 curriculum English education has been arranged in term of competency basic, learning materials and learning activities. For the English instruction of tenth grade, the materials were consisted of social function, text structure, language component, topics means grammatical elements. 
JOSAR, Vol. 1 No. 1 March 2019; p-ISSN: 2502-8251; e-ISSN: 2503-1155

Copyrights@Balitar Islamic University, Blitar-Indonesia https://ejournal.unisbablitar.ac.id/index.php/josar

The grammatical elements included integrative and declarative in simple past tense, past continuous, present perfect tense.

Those grammatical elements were required to be taught in the basic competence. It was important to find out the reality at schools whether these grammatical elements were taught independently and to find out potency as well as problems to be concerned. In order to obtain such data, the researcher conducted field study. Using the principals of case study, the researcher conducted observation, interview and document analysis at SMAN 4 Blitar. The observation conducted in three types of observation which were covered descriptive observation, selective observation, and focus observation. The interview conducted through in-depth interview by using purposive sampling to determine first key informant, and by using snowball technique to determine the next keys informant. The document analysis covered by analyzing lesson plan and students' mean score based on base competence 3.6. The result of observation, interview and document analysis were showed that $X$ grade students lack in grammar achievement.

In order to make sure that it would be applicable, the researcher already checked theories and research result. The related theories of the research that conveyed by Arsyad (2009:4) teaching media is a media that brings instructional purpose of messages or information of learning. The media is developed through produce a product as learning media in form of book, video, educational game and etc. This statement supported by Donmus, in Derakhshan and Khatir (2015: 39) that state the value of educational games has been increasing in language education since they help to make language education entertaining. To teach grammar in fun learning have to use game as teaching and learning media. It also explained by Vernon, in Ibrahim (2016: 55) said, the theory of intrinsic motivation might also give some insight about teaching grammar through games actually works. 
JOSAR, Vol. 1 No. 1 March 2019; p-ISSN: 2502-8251; e-ISSN: 2503-1155

Copyrights@Balitar Islamic University, Blitar-Indonesia https://ejournal.unisbablitar.ac.id/index.php/josar

The researcher also checked the previous study by Kirana entitled Developing Education Game Finding Nevi as English Learning Media Tenses in Senior High School year 2015. The research was Research and Development which used ten steps by Sugiyono's model. The research objective was to solve the problem in lacking of students' grammar achievement and produce educative game of English material to senior high school. It used as a learning media of irregular verbs and tenses based Adobe Flash CS6, to increase students' grammar achievement and students' learning motivation. It has been obvious that the web base game could be contribute to increase grammar acquisition achievement. Therefore, the researcher developed "English Keren Rek (EKR) Web Base Game Application Model to Enrich X Grade Students' English Grammar Achievement". This model expected could be improved English grammar acquisition.

\section{RESEARCH METHOD}

This research employed both qualitative and quantitative approaches. The qualitative approach concern with natural phenomena having data in the form of words (verbal and written) and deeds of humans (Afrizal, 2014: 13). This would be related to the first phase and the second phase of this research which were policy study, case study (fields study), literature study and design of development. The quantitative approach would be used to try-out the model by using experimental study. Within these approaches, the researcher determined design of research.

The design of this research was Research and Development $(\mathrm{RnD})$ that would focused in developing English Keren Rek (EKR) web base game application model as English teaching and learning media. The researcher adapted the Sugiyono's model into the following framework. 
JOSAR, Vol. 1 No. 1 March 2019; p-ISSN: 2502-8251; e-ISSN: 2503-1155

Copyrights@Balitar Islamic University, Blitar-Indonesia https://ejournal.unisbablitar.ac.id/index.php/josar

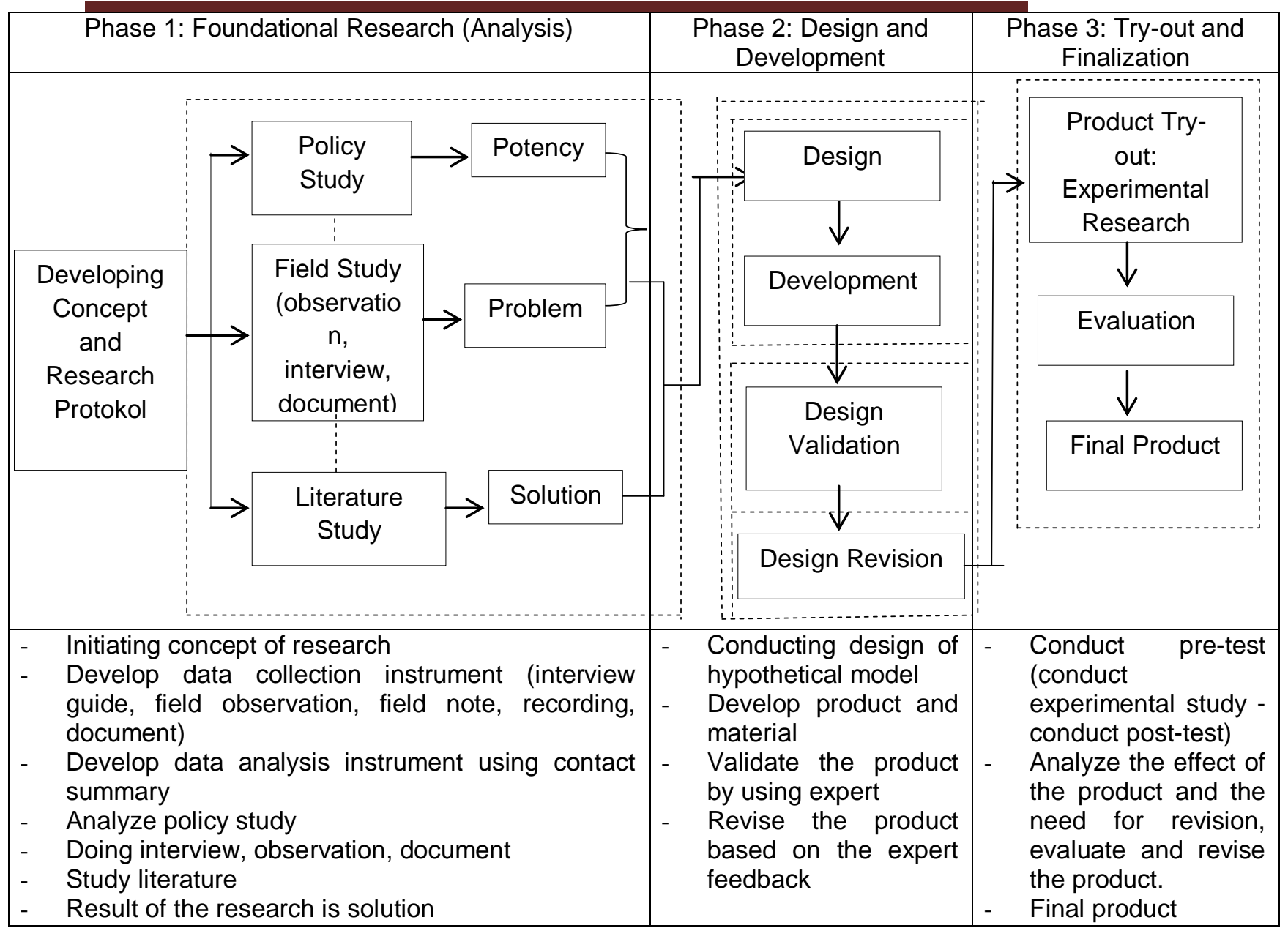

Figure Research Framework Adapted from Sugiyono (2016: 298) with Reference to DSS Model (2018)

This framework was elaborated into the following working procedures:

The phase one was foundational research contained policy, field, and literature studies. The policy study concerned the analyzes of policy to find out potency. The field study selected by using criteria of field study which was done by using observation, interview, and document to obtain the information on the problem. The literature study was the analysis of research results and theories find out the solution. Both the policy and literature studies used content analysis. The field study was analized by using Miles and Hubberman (2014:10) interactive model. 
JOSAR, Vol. 1 No. 1 March 2019; p-ISSN: 2502-8251; e-ISSN: 2503-1155

Copyrights@Balitar Islamic University, Blitar-Indonesia https://ejournal.unisbablitar.ac.id/index.php/josar

The data collected through three types of observation which were concluded descriptive observation, selective observation, and focused observation. There was analyzed by using observation contact summary after being reduced in the process of analysis from field notes. The data collected through interview by using purposive sampling to determine the first key informant and snowballing to determined next keys informant. The interview conducted by using in-depth interview through inserting probing. It was to find out the specific information which was analyzed by using interview contact summary after being reduced in process of analysis by using transcription. The data collected through documentation were directly taken from records of students' mean score and lesson plan.

Based on the result of analysis in phase one, the researcher designed the product by refering to the principles of instructional development which called ADDIE Model by Branch (2009: 8). explained that instructional design is an interactive process of planning performance objectives, selecting instructional strategies, choosing media and selecting or creating materials, and evaluation. The design development result was validated by experts which consisted material, material (grammar), English learning, and media based on criteria of validation. After design validation, the researcher conducted design revision based on validation result.

The product has been revised, the researcher conducted product try-out by using one group pre-post test experimental design, the subjects of this research was taken by using purposive sampling. The subjects were $X$ grade students of MIPA 1 to try-out product and $X$ grade students of MIPA 4 to conduct validity and reliability test. The pre and post tests were conducted in form of multiple choice consisting 50 questions. The validity and reliability of the test were measured by using correlation technique, alpha corn-batch by using 
JOSAR, Vol. 1 No. 1 March 2019; p-ISSN: 2502-8251; e-ISSN: 2503-1155

Copyrights@Balitar Islamic University, Blitar-Indonesia https://ejournal.unisbablitar.ac.id/index.php/josar

split half technique, and questions item analysis. Result of the average scores were compared and tested using the t-test formula. After having the try out, the product was evaluated by experts by using the evaluation criteria. Upon having the approval from all experts, the product was finalized for limited publication.

\section{RESEARCH RESULT AND DISCUSSION}

The final model of English Keren Rek (EKR) web base game application model was in the form of web base game application which operated and used softcopy of web game file as a game data and the Xampp 1.7.3 as supplementary application to help it could be run and could be accessed through google chome in offline web. It also could help the grammar achievement. Theoretically, it was the theories of English grammar learning that was contributed in teaching English. In this context was enable that was the increasing grammar occurred because of the presence of visual. It turned out to confirm the theory of teaching and learning media by Branch (2009: 98) who stated that visual students learn most through the visual sense. On the other hand, result of this research also in line with the theory of intrinsic motivation by Vernon, in Ibrahim (2016) who stated that teaching grammar through games actually works. The result of this research turned out to confirm the previous study by Kirana (2015) which showed that the usage of Adobe Flash CS6 as learning media could increase the students' grammar achievement especially in irregular verbs and tenses. These mean that the final model of this research supported these theories, but did not duplicate the theories and previous study concerns. This research reveals original new model and product.

Practically, the final model already experienced improvement during the research based on the field research in situational, such as the requirement of learning materials and some button as part of 
JOSAR, Vol. 1 No. 1 March 2019; p-ISSN: 2502-8251; e-ISSN: 2503-1155

Copyrights@Balitar Islamic University, Blitar-Indonesia https://ejournal.unisbablitar.ac.id/index.php/josar

product to support the product easy to teach and implemented. Therefore, because this research could be applied in other situation and condition, but it did not state that the research result made the situation wider in generally. However, it was appropriate with research result that was supported with interview respond with teacher and students after using the product. The interview result could be concluded that based on teacher's statement stated that the media assisted to help teacher to deliver the materials of English grammar effectively and efficiently. It also conveyed by students that the media helpful to help students to learn and achieve the tenses grammar materials easily and created fun learning. Therefore, the product contributed to the teaching and learning English practically and helpful teacher and students. English Keren Rek (EKR) web base game application model could be applied practically by valuing procedures which were covered of teacher's preparation to teach such as prepared the lesson plan, understood the media and how to operate the media, mastery the materials, and used the relevant sources.

Before conducting experimental study, the researcher conducting validity and reliability of test to measure the validity and reliability test before using as pre-test. It conducted in twice. The first test result was calculated based on alpha corn-batch by using split half technique, correlation technique, and questions item analysis. Based on alpha corn-batch and correlation technique were showed that the all questions were reliable. But, based on the questions item analysis showed 16 questions were not valid and not reliable. Therefore, the questions were not valid and reliable have to change and conducted test again. The second test showed that all questions were valid and reliable based on calculation result of questions item analysis. So that, the questions of second test could be used to pretest as a part of experimental study. 
JOSAR, Vol. 1 No. 1 March 2019; p-ISSN: 2502-8251; e-ISSN: 2503-1155

Copyrights@Balitar Islamic University, Blitar-Indonesia https://ejournal.unisbablitar.ac.id/index.php/josar

The result of experimental study revealed the valuing that posttest result was better than pre-test result. It showed as follows.

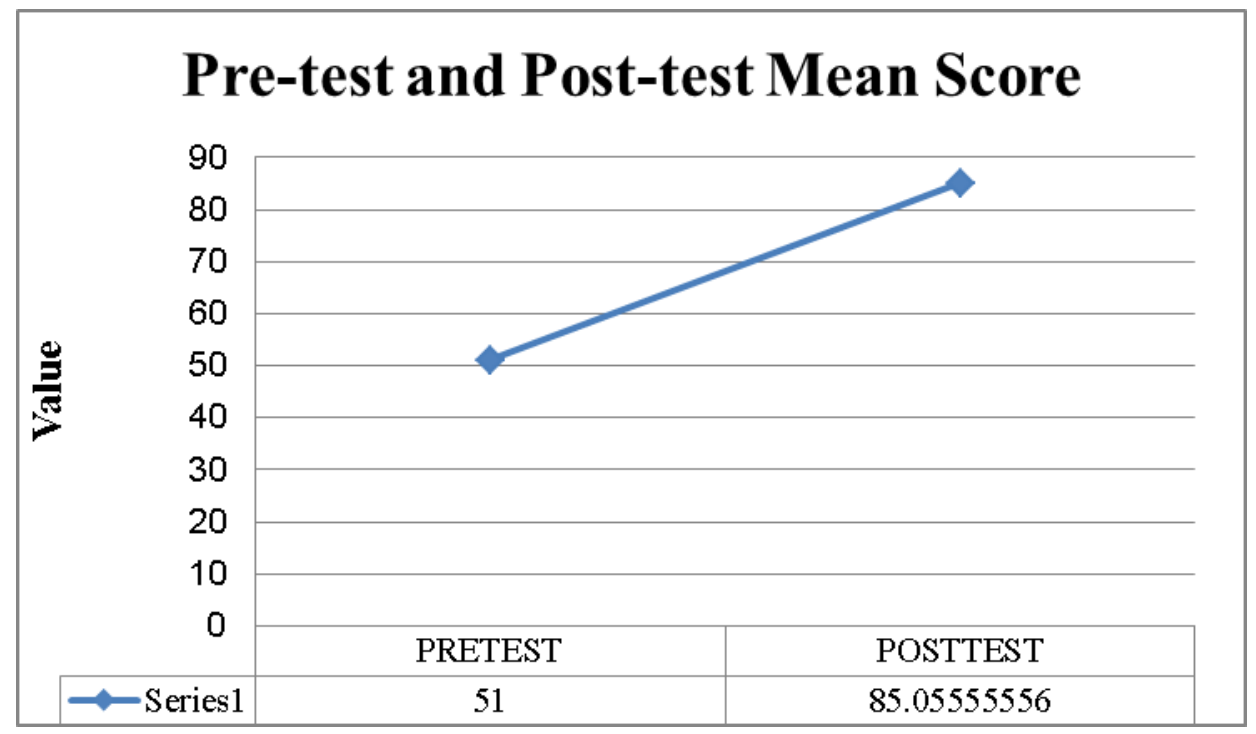

From the mean score result of pre-test was increased that showed in the result of post-test. It was meant that mean score of pre-test was 51 and post-test 85.05555556 has increased mean score was $60 \%$. So that, English Keren Rek (EKR) was effective to use as teaching and learning media to help students achieved grammar, especially tenses.

The mean scores of pre-test and post-test also calculated using t-test to know the properness of the product. It showed that the value of t-test was $-35.556<t_{\text {table }} 2.03011$ which was means $\mathrm{Ha}$ accepted, the English Keren Rek (EKR) Web Base Game Application Model was proper to use as a teaching and learning media to enrich $X$ grade students' English grammar achievement.

This research revealed three main things which were (1) the effective model of web base game application model for learning grammar was English Keren Rek (EKR) Web Base Game Application Model, (2) the procedures of using the English Keren Rek (EKR) Web Base Game Application Model based game was teacher had to achieve the tenses materials; teacher had to know and 
JOSAR, Vol. 1 No. 1 March 2019; p-ISSN: 2502-8251; e-ISSN: 2503-1155

Copyrights@Balitar Islamic University, Blitar-Indonesia https://ejournal.unisbablitar.ac.id/index.php/josar

understand what the English Keren Rek (EKR) and how to operate it; teacher had to prepare the lesson plan by paid attention of time allotment, materials, relevant learning source, learning media and learning tools, learning approach, learning strategy, learning method, grammar evaluation which were appropriate with 2013 curriculum, syllabus, and students' requirement; in the classroom, teacher had to manage class which covered created good situation and enjoy learning, had to check students preparation of teaching and learning activities, give apperception related the material and learning by used media, gave motivations to learn tenses materials by used media, teacher accompanied the students by guided them to operate the media, teacher gave opportunities to students to ask and answer questions and also gave feedback in each activities, teacher evaluate students' activities based on the game in form of students got game scores and students' skill in operated game, teacher evaluate the students' knowledge by gave formative test to each activities or whole activities to evaluate the grammar achievement. (3) The English Keren Rek (EKR) Web Base Game Application Model turned out to influence the improvement of grammar achievement in $\mathrm{X}$ grade of second semester based on the result of pre-test and post-test which were calculated by using t-test.

The result of experimental study showed that the English Keren Rek (EKR) web base game application model theoretically strengthened the previous research results in which the visual media were able to enrich students' grammar achievement and showed the indication that a visual interactive game enabled to increase students' motivation and learning style effectively (Branch, 2009: 98 and Vernon, in Ibrahim, 2016). 
JOSAR, Vol. 1 No. 1 March 2019; p-ISSN: 2502-8251; e-ISSN: 2503-1155

Copyrights@Balitar Islamic University, Blitar-Indonesia https://ejournal.unisbablitar.ac.id/index.php/josar

\section{CONCLUSION}

The Implementation of English Keren Rek (EKR) Web Base Game Application Model

The implementation procedures by using the English Keren Rek (EKR) Web Base Game Application Model divided five stages which were (1) personal teacher preparation; (2) classroom instruction; (3) evaluation process; (4) final evaluations; (5) feedback. It was explained as follows.

Personal teacher preparation covered teacher had to (1) require the requisite of professional teacher and competence in their sector such as achieve the tenses materials; (2) prepare learning media and tools; (3) know and understood what the English Keren Rek (EKR) and how to operate it; (4) prepared and developed the lesson plan. In classroom instructions by using the media, teacher had to do (1) orientation; (2) teacher gave apperception related the material; (3) teacher gave motivation; (4) teacher did pre-learning by explaining materials, learning scenario, criterion base competence. In process evaluation covered (1) how the students followed the learning activities; (2) the students understood to use the media; (3) the students able to answer the questions in the form of test. In giving feedback to whole learning activities, teacher together with students reflected the learning activities by reviewing the activities which already done and gave reinforcement to help students remembered the lesson.

\section{The Effectiveness of English Keren Rek (EKR) Web Base Game} Application Model

The effectiveness of English Keren Rek (EKR) Web Base Game Application was measured through result of pre-test and post-test. Before the questions used to pre-test, it has already measured the validity and reliability of test. It conducted in two test. The first validity 
JOSAR, Vol. 1 No. 1 March 2019; p-ISSN: 2502-8251; e-ISSN: 2503-1155

Copyrights@Balitar Islamic University, Blitar-Indonesia https://ejournal.unisbablitar.ac.id/index.php/josar

and reliability test result was calculated based on alpha corn-batch by using split half technique, correlation technique, and questions item analysis. Based on alpha corn-batch (0.999) by using split half technique showed 0.997 to questions number 1 up to 25 and 0.998 to questions number 26-50 which were concluded the all questions were reliable. Based on correlation technique showed that $r_{\text {hitung }}>$ $r_{\text {tabel }}$ which were concluded the all questions were valid. But, based on the questions item analysis showed 16 questions were not valid and not reliable. Therefore, the researcher changed the questions were not valid and conducted the second validity and reliability test. The result of second validity and reliability test based on the questions item analysis showed the all questions were valid. It could be concluded that the questions could be used to pre-test.

Based on the experimental research result showed on the result of pre-test and post-test, the product gave the significant effect. It was explained that value of t-test was $-35.556<t_{\text {table }} 2.03011$ by sig. 0,05 . It calculated used SPSS version 21 and increased value of pretest to post-test was $60 \%$ which were could be concluded that the product was appropriate and effective to implement for $X$ grade students in second semester to enrich English grammar achievement.

\section{SUGGESTION}

In developing of English Keren Rek (EKR) Web Base Game Application Model could be implemented and added in theoretical English teaching and learning, theoretical of teaching and learning used media, theoretical teaching grammar by using media web base game application which already proved that the media was very effective to teach English grammar. It also used relevant theory to develop and enrich theoretical research. 
JOSAR, Vol. 1 No. 1 March 2019; p-ISSN: 2502-8251; e-ISSN: 2503-1155

Copyrights@Balitar Islamic University, Blitar-Indonesia https://ejournal.unisbablitar.ac.id/index.php/josar

Practically, the product implemented for school, for teacher, for students, and for other developer. The English Keren Rek (EKR) Web Base Game Application Model needed maximally support from school. In using the English Keren Rek (EKR) Web Base Game Application Model, the teacher suggested to recognize and accustomed to use English Keren Rek (EKR) Web Base Game Application in teaching learning activities, did the preparation before teaching by used English Keren Rek (EKR) Web Base Game Application Model as teaching and learning media. If, the materials of media were lack, teacher should be found out the other relevant material. The teacher also suggested and supported students to recognize and accustomed to use English Keren Rek (EKR) Web Base Game Application Model in grammar achievement. The student trained in teaching and learning formally discussed with teacher and individually. For other researcher who interested to conduct research and development suggested to use the research result of English Keren Rek (EKR) Web Base Game Application Model as a reference in the form of replica or created a new product of research and development, used to as literature study in developed the similar product which this research already conducted limitedly by research was focusing to visual media and motivation, so that it needed research in-depth and continuously.

\section{REFERENCES}

Afrizal. 2014. Metode Penelitian Kualitatif: Sebuah Upaya Mendukung Penggunaan Penelitian Kualitatif dalam Berbagai Disiplin Ilmu. Jakarta: PT Raja Grafindo Persada, p. 13.

Arsyad, A. 2009. Media Pembelajaran. First Edition. Jakarta: Raja Grafindo Persada.

Branch, R. 2009. Instructional Design: The ADDIE Approach. New York: Springer

Derakhshan, A. and Khatir, E. 2015. Journal of Applied Linguistics and Language Research. (Online). Journal. Volume 2, Issue 3, 2015, pp. 39-47. 
JOSAR, Vol. 1 No. 1 March 2019; p-ISSN: 2502-8251; e-ISSN: 2503-1155

Copyrights@Balitar Islamic University, Blitar-Indonesia https://ejournal.unisbablitar.ac.id/index.php/josar

Ibrahim, N. 2016. Games for Teaching Grammar to Young Learners. Indonesian Journal of Integrated English Language Teaching Vol. 2. State Islamic University of Sultan Syarif Kasim Riau.

Kirana. 2015. Pengembangan Game Edukasi Finding Nevi sebagai Media Pembelajaran Tenses dalam Bahasa Inggris di SMA. Published Thesis. Yogyakarta: Technical Information Department Yogyakarta State University

Law of Educational and Cultural Minister. Basic Framework and Curriculum Structure of Senior High School. State Gazette of the Republic of Indonesia Year 2013, No. 69. Secretariat State. Jakarta.

Miles and Hubberman. 2014. Qualitative Data Analysis: A Methods Sourcebook. Third Edition. United States of America: Library of Congress Cataloging-in-Publication Data.

Republic of Indonesia. 2003. Constitution of the Republic of Indonesia (UUD) number 20 year 2003 about The National Education System. State Gazette of the Republic of Indonesia Year 2003, No. 20. Secretariat State. Jakarta.

Sugiyono. 2009. Metode Penelitian Pendidikan: Pendekatan Kuantitatif, Kualitatif, dan R\&D. Bandung: Alfabeta

Sugiyono. 2011. Metode Penelitian Pendidikan: Pendekatan Kuantitatif, Kualitatif, dan R\&D. Bandung: Alfabeta.

Supriyono. 2017. Supervisi Pembelajaran di Sekolah Menengah Pertama (Studi Multi Situs pada SMPN 1, SMPN 2, dan SMPN 4 Kota Blitar. Unpublished Disertation. Blitar: Balitar Islamic University. 